\title{
PERCEPÇÃO ESTÉTICA: a influência do modernismo no olhar da era tecnológica
}

\author{
A esthetic perception: the influence of the modernism \\ in the look of the technological age
}

\section{Flávia Campos Junqueira}

Mestranda em Comunicação Social pela Universidade Federal de Juiz de Fora (UFJF), na linha de pesquisa Estética, Redes e Tecnocultura, Graduada em Comunicação Social pela UFJF, Juiz de Fora, MG - Brasil, e-mail: flavinha.junqueira@yahoo.com.br

\section{Resumo}

O século XX foi marcado por grandes transformações ao longo de suas décadas. Estudos de pensadores que viveram boa parte desse período são agora muito utilizados para que tais transformações possam ser analisadas e melhor compreendidas, visto que, muitas vezes, no calor das mutações, certos aspectos importantes podem permanecer encobertos. O processo de desenvolvimento do fim do século XIX trouxe consigo questionamentos que possibilitaram grandes avanços sociais, econômicos e culturais. Com base nesses avanços culturais, o objetivo deste trabalho é compreender como a percepção estética humana foi alterada, até que o homem se tornasse habituado aos estímulos sensoriais que recebe hoje.

Palavras-chave: Percepção estética. Modernismo. Cinema. Tecnologia. Cibercultura.

\begin{abstract}
Century XX was marked by great transformations throughout its decades. Thinkers who had lived good part of this period now are very used so that such transformations can be analyzed and better understood, since, many times, in the heat of the mutations, certain important aspects can remain hidden. The process of development of the end of century XIX brought questionings that make possible great social, economic and cultural advances. He will be this last one that it will lead this work, in order in helping them to understand as our aesthetic perception was modified, until we became them accustomed the sensorial stimulus that we receive today.
\end{abstract}

Keywords: Aesthetic perception. Modernism. Cinema. Technology. Cyberculture. 


\section{INTRODUÇÃO}

Durante todo o processo da história cultural, houve a passagem da cultura oral para a escrita, avançando sucessivamente para a imprensa, para a cultura de massas e para a cultura das mídias, até a atual cultura digital. Esta cronologia nos permite compreender melhor as transformações vividas pela sociedade para abrangermos a percepção estética a partir de uma perspectiva histórica.

Conforme aponta Pierre Lévy, a escrita foi responsável pela universalização do pensamento. $\mathrm{Na}$ cultura oral, o contexto no qual se passava determinado evento era importante para a compreensão do fato acontecido. A escrita possibilitou que a informação fosse passada adiante, para diferentes contextos culturais ou sociais, sem perder o sentido (LÉVY, 1999, p. 114).

A escrita abriu um espaço de comunicação desconhecido pelas sociedades orais, no qual tornava-se possível tomar conhecimento das mensagens produzidas por pessoas que encontravam-se a milhares de quilômetros, ou mortas há séculos, ou então que se expressavam apesarde grandes diferenças culturais ou sociais.

Mais à frente no tempo, podemos dizer que a primeira grande transformação pela qual a sociedade passou e que teve papel mais próximo para chegarmos à percepção estética atual foi a Revolução Industrial do século XVIII. A partir dela, uma grande mudança ocorreu nas bases materiais da economia, sociedade e cultura. A esse respeito, Manuel Castells afirma que

ao educar seus cidadãos e promovera organização gradual da economia em torno de conhecimentos e informação, a sociedade industrial preparou o terreno para a capacitação da mente humana para quando as novas tecnologias da informação fossem disponibilizadas (CASTELLS, 2000, p. 114).

O fato é que no mérito cultural, a industrialização iniciada no século XVIII alcançou seu auge no fim do século XIX e início do XX, ao originar linguagens advindas dos meios criados a partir dela. Os vanguardistas modernos, nascidos em meio às transformações consequentes da industrialização, foram os primeiros a perceber que os recursos tecnológicos como a fotografia e o cinema seriam importantes fontes de produção de novas linguagens artísticas. Tanto a nova organização social, propiciada pela urbanização, quanto as linguagens vanguardistas criadas na época seriam responsáveis pela nova percepção estética que viria a se formar.

Em 1968, Jürgen Habermas, ao tratar da técnica nos tempos modernos, afirmou que "na medida em que a técnica e a ciência pervadem as esferas institucionais da sociedade e transformam assim as próprias instituições, desmoronam-se as antigas legitimações" (HABERMAS, 1994, p. 45). Abordando aqui a racionalidade em Weber, Habermas explica que a racionalização corresponderia à industrialização do trabalho social e, consequentemente, à dissolução da ação instrumental em outros âmbitos da vida, como a tecnificação do tráfego e da comunicação. Associando esta premissa ao texto $A$ obra de arte na era de sua reprodutibilidade técnica, de Walter Benjamin, poderíamos relacionar a decorrência desta racionalização com a perda da aura, consequência da reprodução em larga escala possibilitada pelo avanço industrial.

Muitos debates acerca deste assunto limitamse a considerar a perda da aura como o fim da arte autônoma, quando o ponto crucial nesta discussão é a refuncionalização da arte que surgiu a partir dela. $\mathrm{O}$ próprio autor afirma que poucos se deram conta deste fato. A arte, ao emancipar-se do valor de culto, altera a sua própria natureza (BENJAMIN, 1994, p. 176).

\section{Cinema e a ascensão do visual}

Benjamin vêo cinema como a característica marcante do século em que a reprodutibilidade gerou novos conceitos para a obra de arte, conceitos que permitiram mudanças na recepção do espectador. Nas palavras do autor:

o filme serve para exercitar o homem nas novas percepções e reações exigidas por um aparelho técnico cujo papel cresce cada vez mais em sua vida cotidiana. Fazer do gigantesco aparelho técnico do nosso tempo o objeto das inervações humanas - é essa a tarefa histórica cuja realização dá ao cinema o seu verdadeiro sentido (BENJAMIN, 1994, p. 174). 
Influenciados pelas ideias de Benjamin, é possível afirmar que o cinema representou a ascensão do visual como discurso social e cultural, fato que se tornou comum na vida moderna. Este foi um importante fator responsável pela reestruturação do olhar. Benjamin e seu contemporâneo Siegfried Kracauer entendiam a modernidade como um momento em que a experiência subjetiva foi fortemente intensificada por estímulos. As cidades eram então repletas de imagens, cartazes e jornais ilustrados, além da velocidade que se impunha sobre a população pelos bondes elétricos e, logodepois, automóveis. Sobre o hiperestímulo advindo das novidades modernas, Ben Singer coloca que

como um conceito cognitivo, a modernidade aponta para o surgimento da racionalidade instrumental como a moldura intelectual por meio da qual o mundo é percebido e construído. Como um conceito socioeconômico, a modernidade designa uma grande quantidade de mudanças tecnológicas e sociais que tomaram forma nos últimos dois séculos e alcançaram um volume crítico perto do fim do século XIX: industrialização, urbanização e crescimento populacional rápidos; proliferação de novas tecnologias e meios de transporte; saturação do capitalismo avançado; explosão de uma cultura de consumo de massa e assim por diante (SINGER, 2001, p. 115).

Benjamin coloca que a recepção aberta à reprodução, característica que alcançou seu ápice com o cinema, teve como principal impulsor o movimento artístico do Dadaísmo. O autor destaca que os "dadás" "aniquilavam impiedosamente a aura de suas criações, que eles estigmatizavam como reprodução, com os instrumentos da produção" (BENJAMIN, 1994, p. 191). O dadaísmo abriu caminho para uma atenção ágil por parte do receptor.

O dadaísmo colocou de novo em circulação a fórmula básica da percepção onírica, que descreve ao mesmo tempo o lado tátil da percepção artística: tudo o que é percebido e tem caráter sensívelé algo que nos atinge. Com isso, favoreceu a demanda pelo cinema, cujo valor de distração é fundamentalmente de ordem tátil, isto é, baseia-se na mudança de lugares e ângulos, que golpeiam intermitentemente o espectador (BENJAMIN, 1994, p. 192).
E, quanto à mudança que o cinema provocou na atenção do espectador, o autor continua, afirmando que a imagem

[...] não pode ser fixada, nem como um quadro, nem como algo de real. A associação de idéias do espectador é interrompida imediatamente, com a mudança da imagem. Nisso se baseia o efeito do choque provocado pelo cinema, que, como qualquer outro choque, precisa ser interceptado por uma atenção aguda. O cinema é a forma de arte correspondente aos perigos existentes mais intensos com os quais se confronta o homem contemporâneo (BENJAMIN, 1994, p. 192).

Seguindo este pensamento, Mirian Hansen trabalha com a ideia de que o cinema foi o meio no qual os efeitos da modernidade mais podiam ser discutidos. Hansen coloca a "racionalização", a "desmitologização", a "alienação" e a "reificação" como categorias da lógica da modernidade (HANSEN, 2001, p. 508) e, embasada nas ideias de Kracauer, afirma que o autor alemão desenvolve certo fascínio pelas "novas formas de entretenimento que transformam a 'fusão entre pessoas e coisas' em um princípio criativo” (HANSEN, 2001, p. 510).

Todo este contexto pode ser associado às transformações pelas quais passamos na atualidade, transformações estasiniciadas hápelo menos um século.

\section{Cultura das mídias, pré-domínio do digital e a afirmação da cibercultura}

O rápido avanço tecnológico influencia diretamente nossa intuição estética e novas concepções vão se formando como acontecia há cem anos. "Descobertas no domínio tecno-científico modificam o alcance e a função da imagem em nossa civilização urbana. Elas incidem sobre as formas de sentir e pensar do homem comum" (LUZ, 1996, p. 49).

A comparação entre os períodos de transição fica mais clara se observarmos as características dadas por Rogério Luz ao momento atual: "Privilegia-se o sentido de ruptura do fenômeno, abandona-se uma concepção continuista da história das formas de representação, marca-se a abolição do passado e da tradição para melhor pensar o novo e agir valorativamente sobre ele" (LUZ, 1996, p. 49). 
A recepção do homem atual deixou de ser um processo contínuo, linear, para se tornar fragmentado. Benjamin chamou esta experiência fragmentada de percepção de choque. Para ele, nas palavras de Leo Charney, "a irrupção da modernidade surgiu nesse afastamento da experiência concebida como uma acumulação contínua em direção a uma experiência de choques momentâneos que bombardearam e fragmentaram a experiência subjetiva como granadas de mão" (CHARNEY,2001,p. 394). Ao discutiro efeito das novas imagens sobre a sociedade, Rogério Luz defende que a realidade virtual, fruto dessas novas imagens e comum a nosso tempo, implica uma nova relação do homem com o mundo material e social, num espaço-tempo simulado (LUZ, 1996, p. 49). Somos hoje capazes de responder a estímulos num contexto virtual de ação e percepção.

Para que chegássemos a tal estado de recepção, Lúcia Santaella afirma que passamos pela cultura das mídias, um período transitório que nos levaria à cibercultura. $\mathrm{O}$ avanço das tecnologias, nos últimos 30 anos, possibilitou o aparecimento de uma cultura "do disponível", tendo como principal característica propiciar a escolha e o consumo individualizados. Nas palavras de Santaella:

essas tecnologias, equipamentos e as linguagens criadas para circularem neles têm como principal característica propiciar a escolha e consumo individualizados, em oposição ao consumo massivo. São esses processos que considero como constitutivos de uma cultura das mídias. Foram eles que nos arrancaram da inércia da recepção de mensagens impostas de fora e nos treinaram para a busca da informação e do entretenimento que desejamos encontrar (SANTAELLA, 2007, p. 4).

A intensificação das misturas entre os meios de comunicação seria a característica marcante da cultura das mídias, levando à mescla das formas de comunicação e de cultura. Com isto, influenciou o processo de recepção dos indivíduos. Se antes parávamos para assistir televisão, passamos a assistila enquanto falamos ao telefone e pesquisamos no computador.

Desta maneira, nossa sensibilidade se preparou para a chegada dos meios digitais. Lévy insiste que os novos dispositivos informacionais e comunicacionais são os maiores portadores de mutações culturais, e afirma que o público desta cultura das mídias permanece envolvido emocionalmente a um macrocontexto, no qual, porém, nunca pode ser ator.

A televisão, interagindo com as outras mídias, faz surgir um plano de existência emocional que reúne os membros da sociedade em uma espécie de macro-contexto flutuante, sem memória, em rápida evolução. [...]. É preciso conceder a McLuhan o mérito de ter descrito, pela primeira vez, o caráter das sociedades midiáticas. A principal diferença entre o contexto midiático e o contexto oral é que os telespectadores, quando estão implicados emocionalmente na esfera dos espetáculos, nunca podem estar implicados praticamente. Por construção, no plano de existência midiática, jamais são atores (LÉVY, 1999, p. 116-117).

Dessa forma, a cultura das mídias constitui, principalmente, um período de transição para a forma cultural vigente nos dias de hoje, que chamamos de cibercultura. Esta seria a mundialização vigente que constitui um fenômeno nunca vivido antes, a convergência das mídias. A navegação abstrata em paisagens de informações e conhecimentos, a criação de grupos de trabalhos virtuais em escala mundial, as inúmeras formas de interação possíveis entre os cibernautas e seus mundos virtuais criam uma enorme quantidade de comportamentos inovadores.

Da prevalência da cultura oral ao advento da cibercultura, formou-se uma "miscelânea cultural", em que uma nova forma de cultura não suprime a anterior, mas, antes, a integra e a engloba. Nesta perspectiva, Santaella apresenta a seguinte reflexão:

Cada ciclo cultural funciona socialmente de maneiras diversas. [...] Os distintos tipos de mídias e as eras culturais que conformam são inseparáveis das formas de socialização que são capazes de criar, de modo que o advento de cada nova mídia traz consigo um ciclo cultural que lhe é próprio e que fica impregnado de todas as contradições que caracterizam o modo de produção econômica e as consequentes injunções políticas em que um tal ciclo cultural toma corpo (SANTAELLA, 2007, p. 5).

Assim sendo, a cibercultura agrega as culturas emergidas a priori, como uma característica da 
atualidade. Neste contexto de convergência midiática, a experiência estética atual pode ser entendida como um banco de dados.

\section{Novas experiências: banco de dados e o receptor ativo}

A compreensão é construída com o uso de ferramentas que permitem uma busca não-linear a partir de diferentes fontes, que podem ser verbais, audiovisuais, materiais ou virtuais. A formação intelectual de hoje vem não apenas dos livros pedagógicos, mas também da televisão, da internet ou mesmo de vídeogames. O conhecimento nasce a partir da construção dos dados oriundos de diferentes meios e, com isto, o receptor seleciona o que lhe é ou não interessante, acumulando ou eliminando dados de acordo com sua seleção. Desta forma, nossa percepção se configura como alinear e dispersa, fragmentada, comprovando o que foi afirmado anteriormente com Charney.

Lev Manovich defende a ideia de que a montagem cinematográfica seria a responsável pela relação que temos hoje com a tecnologia. A montagem teria sido a grande chave do século XX que possibilitou a criação de uma falsa realidade.

Edição, ou montagem, é a tecnologia chave do século XX para criar falsas realidades. Teóricos do cinema distinguiram entre muitos tipos de montagem, mas com a finalidade de esboçar uma arqueologia das tecnologias de simulação que conduziu à composição digital, distinguirei entre duas técnicas básicas. A primeira técnica é a montagem temporal: realidades separadas formam momentos consecutivos no tempo. A segunda técnica é a montagem como um tiro. É o oposto da primeira: realidades separadas formam partes contingentes de uma única imagem. (MANOVICH, 2001, p. 148). ${ }^{1}$
Em uma resenha da obra de Manovich, Irene Machado explica a escolha do cinema pelo autor para abordar a questão do banco de dados: "O saldo positivo imediato é a valorização do caráter cumulativo e das interligações entre formas e sistemas culturais. É como banco de dados que as mídias anteriores ao computador podem operar diferentes modelizações da linguagem em novos suportes" (MACHADO, 2002, p. 220). Manovich exemplifica sua questão citando uma sequência do filme $O$ homem com uma câmera:

Em uma das sequências de $O$ homem com uma câmera, Vertov nos mostra um operador de câmera na parte traseira de um automóvel em movimento. Enquanto está sendo carregado para frente pelo automóvel, ele gira a manivela de sua câmera. Uma volta, uma repetição, criada pelo movimento circular da manivela, dá início a uma progressão de eventos - uma narrativa muito básica que é também essencialmente moderna (MANOVICH, 2001, p. 316). ${ }^{2}$

O fato é que atualmenteé possível perceber com clareza que os processos cognitivos habituados à não-linearidade das linguagens tecnológicas atingiram esse ponto graças às rupturas modernas. Como consequência desta nova capacidade cognitiva do homem, é possível dizer que a posição do sujeito como simples receptor está mudando. Pode-se agora ser também emissor diante das novas tecnologias.

Para Lévy, a difusão no ciberespaço é uma forma de interação no centro de uma circunstância, onde cada um contribui, explorando-a de forma própria. Nas mídias convencionais, a difusão se daria a partir de um centro, passando uma noção convencionada, encenada do real. No ciberespaço, o sujeito pode serao mesmo tempo receptor e emissor, ou seja, "consomese esse tipo de cultura ativamente - postando, criando páginas, trocando arquivos, consultando, pesquisando

1 No original: "Editing, or montage, is the key twentieth-century technology for creating fake realities. Theoreticians of cinema have distinguished between many kinds of montage, but for the purpose of sketching an archeology of the technologies of simulation that led to digital compositing I will distinguish between two basic techniques. The first technique is temporal montage: Separate realities form consecutive moments in time. The second technique is montage within a shot. It is the opposite of the first: separate realities form contingent parts of a single image" (MANOVICH, 2001, p. 148).

2 No original: "In one of the sequences of Man with a Movie Camera, Vertov shows us a cameraman standing in the back of a moving automobile. As he is being carried forward by the automobile, he cranks the handle of his camera. A loop, a repetition, created by the circular movement of the handle, gives birth to a progression of events - a very basic narrative that is also quintessentially modern" (MANOVICH, 2001, p. 316). 
- ou passivamente - olhando, passeando, navegando como um flaneur digital" (PINHEIRO, 2007, p. 53). Bertold Brecht, em sua Teoria do Rádio (1932) já previa que o caminho da comunicação seria seu abasto provindo dos receptores, tornando-os também emissores.

[...] é preciso transformar o rádio, convertê-lo de aparelho de distribuição em aparelho de comunicação. O rádio seria o mais fabuloso meio de comunicação imaginável na vida pública, um fantástico sistema de canalização. Isto é, seria se não somente fosse capaz de emitir, como também de receber; portanto, se conseguisse não apenas se fazer escutar pelo ouvinte, mas também pôr-se em comunicação com ele. A radiodifusão deveria, consequentemente, afastar-se dos que a abastecem e constituir os radioouvintes em abastecedores. Portanto, todos os esforços da radiodifusão em realmente conferir, aos assuntos públicos, o caráter de coisa pública são realmente positivos (BRECHT, 1932, p. 4).

A elevação do sujeito contemporâneo do posto de simples receptor para um emissor em potencial, serve-nos como indicativo de que novos padrões cognitivos estão surgindo em consequência do impacto das tecnologias digitais. Castells afirma que a velocidade com que as tecnologias se atualizam potencializa o poder de difusão de tal tecnologia entre os usuários que dela se apropriam e a redefinem. Com isso, os usuários, enquanto emissores, assumem o controle, como no caso da internet (CASTELLS, 2000, p. 69).

Porém, ao passo que nossa cognição já atende à demanda tecnológica de recepção-emissão, nossa educação formal ainda regozija o pensamento ultrapassado. Vive-se hoje em um contexto de mídias convergidas e linguagens tecnológicas, no qual, conforme descreve Henry Jenkins,

as crianças estão sendo preparadas para contribuir com uma cultura do conhecimento mais sofisticada. Até agora, nossas escolas ainda se concentram em gerar aprendizes autônomos: buscar informação com outras pessoas ainda é classificado como 'cola'. No entanto, na vida adulta, estamos dependendo cada vez mais dos outros para nos fornecer informações que não conseguimos processar sozinhos. Nosso local de trabalho tornou-se mais cooperativo; nosso processo político tornou-se mais descentralizado; estamos vivendo cada vez mais no interior de culturas baseadas na inteligência coletiva. Nossas escolas não estão ensinando o que significa viver e trabalhar em tais comunidades de conhecimento, mas a cultura popular talvez esteja (JENKINS, 2008, p. 178).

Apocalíptico das tecnologias, Paul Virilio comumente compara os meios de comunicação a armas de guerra para analisar a contemporaneidade, destacando como a questão atual da comunicação:

[...] saber até que ponto os meios de comunicação poderão se comprometer com este "novo espetacular" nascido da urgência das técnicas de tempo real, que de agora em diante infiltra todo o conjunto da comunicação de massa, tanto no Oriente como no Ocidente, abrangendo indiscriminadamente desde informações de ordem política, econômica, social ou jurídica até pseudo divertimentos livres de toda censura: reality base shows, clipes musicais e pornográficos, jogos interativos, etc. (VIRILIO, 1996a, p. 14).

Porém, tal perspectiva analítica de Virilio é apontada como "simplista" por Lévy. Vendo no ciberespaço a possibilidade de uma verdadeira troca de saberes e conhecimentos, Lévy acredita que a crítica deve ser voltada para o futuro, em compasso com o movimento social, sem permanecer presa à grande crítica dos séculos XVIII e XIX (LÉVY, 1999, p. 232). O filósofo alerta que é extremamente importante estarmos abertos à novidade,

que tentemos compreendê-la, pois a verdadeira questão não é ser contra ou a favor, mas sim reconhecer as mudanças qualitativas na ecologia dos signos, o ambiente inédito que resulta da extensão das novas redes de comunicação para a vida social e cultural. Apenas dessa forma seremos capazes de desenvolver estas novas tecnologias dentro de uma perspectiva humanista (LÉVY, 1999, p. 12)

\section{CONSIDERAÇÕES FINAIS}

Por tudo que viemos afirmando até aqui, temos que a esfera tecnológica dissipou-se pela vida cotidiana muito mais do que o público que a absorveu 
pode ter consciência. A difusão da tecnologia e a utilização que a arte do início do século XX fez dela foram fundamentais para chegarmos ao virtual. Teóricos conservadores sugerem que ainda não estamos prontos ou adaptados à linguagem digital. Virilio, por exemplo, coloca como superficial o que sabemos da realidade que vivemos hoje:

Ora, se por um lado conhecemos perfeitamente, ou quase, a realidade da lógica formal da representação pictoral clássica e, em menor grau, a atualidade da lógica dialética que preside à representação foto-cinematográfica, por outro lado temos apenas uma ligeira idéia das virtualidades desta lógica paradoxal do videograma, do holograma ou das imagens digitais (VIRILIO, 1996b, p. 131).

Pois diríamos que estamos sim adaptados e não o sabemos. Ao depararmo-nos com um aparelho eletrônico, a técnica pode ainda nos assustar, mas é inegável o fato de atualmente ser possível trabalhar facilmente com ferramentas tecnológicas, muitas vezes até deixando os manuais de lado. A dificuldade maior está hoje na diferença de marcas e modelos, nos quais os atalhos mudam de códigos, mas a linguagem digital já nos é muito mais familiar do que se pensa.

Para compreendermos as transformações pelas quais passaram nosso processo cognitivo, consideramos ter sido importante voltarmos alguns séculos no tempo. A Revolução Industrial trouxe consigo uma série de implicações que mudariam profundamente a sociedade, não só em sua organização social, mas, sobretudo, nas formas de interação. Os efeitos dela sucedidos levaram a novos hábitos, abrindo portas para a modernidade que viria apressada.

As mudanças que o período vivia exigiam uma mudança de atitude. Não era mais possível negar que conceitos clássicos não correspondiam com a realidade vigente. Desta forma, as vanguardas modernistas foram essenciais na adaptação e evolução do pensamento moderno. Neste contexto, o cinema tornou-se o primeiro meio totalmente industrial de produção da arte, possibilitando aos artistas criarem uma linguagem própria para o meio e tornando-se assim referência para o pensamento modernista. Além disso, foi o primeiro produto artístico capaz de chegar a milhares de pessoas ao mesmo tempo, sendo o mais acessível à população. Diante disso, ele foi o grande responsável pela nova estruturação do olhar.
Com o rápido avanço da tecnologia ao longo do século XX, os dispositivos tecnológicos ficavam cada vez mais acessíveis, e nossa adaptação a tais inovações consequentemente também se tornava mais ágil. Seria, então, inevitável atingirmos o estágio no qual hoje nos encontramos, de total adaptação às linguagens digitais disponíveis. Não podemos negar que nos surpreendemos a cada novidade, mas o tempo que levamos para estarmos ajustados a ela é inegavelmente pequeno.

Em decorrência de todo o trajeto aqui explicitado somos hoje capazes de compor nosso conhecimento a partir de diversas fontes, como diferentes caminhos que podem ser percorridos até um mesmo fim.

Por todas essas premissas, esperamos ter alcançado neste artigo o objetivo de compreender um pouco do momento contemporâneo, acompanhando a evolução da percepção estética a partir dos avanços industriais e tecnológicos vividos entre os séculos XIX e XX.

\section{REFERÊNCIAS}

BENJAMIN, W. A obra de arte na era de sua reprodutibilidade técnica. In: BENJAMIN, W. Magia e técnica, arte e política: ensaios sobre literatura e história da cultura. São Paulo: Brasiliense, 1994. p. 165-196.

BRETCH, B. A teoria do rádio. 1932. Disponível em: $<$ http://www.almanaquedacomunicacao.com.br/artigos/664.html>. Acesso em: 23 out. 2008.

CASTELLS, M. A sociedade em rede. São Paulo: Paz e Terra, 2000.

CHARNEY, L. Num instante: o cinema e a filosofia da modernidade. In: CHARNEY, L.; SCHWARTZ, V. R. O cinema e a invenção da vida moderna. São Paulo: Cosac \& Naify, 2001. p. 386-408.

HABERMAS, J. Técnica e ciência como ideologia. Lisboa: Edições 70, 1994.

HANSEN, M. B. Estados Unidos, Paris, Alpes: Kracauer (e Benjamin) sobre o cinema e a modernidade. In: CHARNEY, L.; SCHWARTZ, V. R. O cinema e a invenção da vida moderna. São Paulo: Cosac \& Naify, 2001. p. 497-557.

JENKINS, H. Cultura da convergência. São Paulo: Aleph, 2008. 
LEVY, P. Cibercultura. São Paulo: Editora 34, 1999.

LUZ, R. Novas imagens: efeitos e modelos. In: PARENTE, A. (Org.). Imagem-máquina. São Paulo: Editora 34, 1996. p. 49-55.

MACHADO, I. Tudo o que você queira saber sobre as novas mídias mas não teria coragem de perguntar a Dziga Viertov. Galáxia: Revista do Programa de Estudos Pós-Graduados em Comunicação e Semiótica da PUC-SP, v. 2, n. 3, p. 219-225, 2002.

MANOVICH, L. The language of new media. Cambridge, Massachusetts: Mit Press, 2001.

PINHEIRO, M. A. Comunicação, consumo e produção de si. In: COUTINHO, I.; SILVEIRA Jr., P. M. (Org.). Comunicação: tecnologia e identidade. Rio de Janeiro: Mauad X, 2007. p. 51-64.

SANTAELLA, L. O papel da mídia no circuito da arte. Disponível em: <http:/ / forumpermanente.incubadora. fapesp.br/portal/.event_pres/simp_sem/pad-ped0/ documentacao-f/conf03/conf03_integra_ls\#ls $>$. Acesso em: 12 nov. 2007.

SINGER, B. Modernidade, hiperestímulo e o início do sensacionalismo popular. In: CHARNEY, L.; SCHWARTZ, V. R. O cinema e a invenção da vida moderna. São Paulo: Cosac \& Naify, 2001. p. 115-148.

VIRILIO, P. A arte do motor. São Paulo: Estação Liberdade, 1996a.

A imagem virtual, mental e instrumental. In: PARENTE, A. (Org.). Imagem-Máquina. São Paulo: Editora 34, 1996b. p. 127-132.

Recebido: 07/10/2009

Received: 10/07/2009

Aprovado: 25/11/2009

Approved: 11/25/2009

Revisado: 18/01/2010

Reviewed: 01/18/2010 